\title{
IMPLEMENTATION OF PROGRAM THE VILLAGE EMPOWERMENT IN RIAU PROVINCE
}

\author{
Trio Saputra, Bunga chintia Utami \\ Fakultas Ilmu Administrasi Universitas lancang Kuning
}

\begin{abstract}
Village empowerment program Implementation (PPD) is a program of the Riau provincial government and the community empowerment directed to rural villages to accelerate poverty reduction through economic development and rural communities. The method used in this research is qualitative discriftif, collecting data through interviews, observation and documentation. The theory used is Edward III of policy implementation. Four variables in the analysis of public policies is Communications, Resources, attitudes and bureaucratic structures. PPD Communications implemented in two ways, namely as a reference guide book uniformity of language policy and technical meetings Tiered as form of direct communication between stakeholders in dealing with problems that arise. Resources consist of human resources and budget. The attitude and commitment of the determination visible implementing decree on the implementation team, commitment to cooperation and commitment duplication of programs by the district / city. While PPD graded organizational structure that is provincial, district / city and district. Each level has a structure and job descriptions of each.
\end{abstract}

Keywords: economic institutions, rural village society

\begin{abstract}
ABSTRAK
Implementasi Program Pemberdayaan Desa (PPD) adalah program pemerintah provinsi Riau dan pemberdayaan masyarakat yang diarahkan ke desa-desa untuk mempercepat pengentasan kemiskinan melalui pembangunan ekonomi dan masyarakat pedesaan. Metode yang digunakan dalam penelitian ini adalah discriftif kualitatif, pengumpulan data melalui wawancara, observasi dan dokumentasi. Teori yang digunakan adalah Edward III dari implementasi kebijakan. Empat variabel dalam analisis kebijakan publik adalah Komunikasi, Sumberdaya, sikap dan struktur birokrasi. Komunikasi PPD diimplementasikan dalam dua cara, yaitu sebagai acuan buku panduan keseragaman kebijakan bahasa dan technical meeting berjenjang sebagai bentuk komunikasi langsung antar pemangku kepentingan dalam menghadapi permasalahan yang timbul. Sumber daya terdiri dari sumber daya manusia dan anggaran. Sikap dan komitmen tekad tersebut terlihat melaksanakan keputusan pada tim pelaksana, komitmen terhadap kerjasama dan duplikasi komitmen program oleh kabupaten / kota. Sedangkan PPD dinilai struktur organisasi yaitu provinsi, kabupaten / kota dan kabupaten. Setiap tingkat memiliki deskripsi struktur dan pekerjaan masing-masing.
\end{abstract}

Kata kunci: lembaga ekonomi, masyarakat desa desa

\section{A.INTRODUCTION}

The welfare of society is not free from the problem of economic development, to improve the welfare of the community can be seen in the presence of open access in poverty reduction programs, health care and educational services. All are intended to improve the quality of the population as a development resource. Interest-oriented development can be an increase in the disadvantaged areas and infrastructure development such 
as construction of public roads, irrigation and water supply system.

Expectations for improving people's lives with their poverty reduction efforts. so that it can solve all problems in the lower layers (low-level problem).Poverty is not just about economic issues, but the end result interrelation of social factors, economic, political and cultural. The poverty anatomical complexity of poverty does not cause problems can only be solved by purely economic approach, but it is related to the dynamics of the social, political and cultural inherent in a community, so poverty is multidimentional and requires synergy. To overcome the poverty problem, the government issued various policies and development programs both central and local government, one of the program is a national program of rural selfempowerment. The program is a government effort to reduce poverty by involving the community, starting from planning, implementation, monitoring and evaluation.

On September 6, 2004 in Pekanbaru, Riau Governor issued the Development village empowerment program through Riau Governor's Decree No. 592 / IX / 2004. Tim Poverty Reduction Committee (TKPK) Riau province was given the task of preparing an appropriate program to address the problem of poverty. Facilitated by DPM who was then named the Agency for Protection and Empowerment (BPPM) TKPK prepare a draft program of empowerment. Target achieved is to increase community economic development activities that are packed in the Village Empowerment Program (PPD). Because it's in the Village Empowerment Program (PPD) demanded to place people or peoples at the center of attention and a target at the same time the main actors in each phase of activity

Riau province alone does not escape from poverty. The main problem faced by the general poverty of people in Riau before the initiative is carried out covering various aspects as follows: (1) access to capital. The problems of poverty like a circle that no tip and base. The poor have limited the ownership of assets and capital that can not increase economies. To get the loan they are usually constrained guarantee. Poor not have the capital can not be trying to not have money can not buy poor production photo production assets so on. (2) the availability of infrastructure. Infrastructure is an important factor driving the economy. Without an adequate infrastructure will be hampered access and the price of goods to be expensive. (3) Institutional society is still not optimally stimulate the economy. Rural economic institutions previously unreachable by villagers due Remote 
control range and long journey times. So that people do not have access to institutions that provide capital to try. (4) Knowledge and Skills. Lack of education of rural communities into one economic problem because without the knowledge of the people are unable to read and develop business opportunities. Prior to this initiative there, no one has combined education, learning, life skills, character development, participation, camaraderie and the provision of operating funds for the community.

Various policies have been selected by the government as an alternative to solving the problem and formulated into public policies must be implemented by administrative bodies and government agencies lower level through the mobilization of financial and human resources Maliki (2012). Target already aspired previously envisaged in the policy objectives, is not likely to achieve optimal implementation policy should support and respect go hand in hand.

According to policy experts, policy implementation is different, but the concept remains the same, policy implementation is a series of translation process of policy direspin form of action development actors consistently in order to achieve the goals and objectives outlined by the policy itself (Tangkilisan 2008) the next Grindle (2009) argues that policy implementation is seen as a process as well as the administration and the political process, which will be determined the successful implementation of a variety of factors.

The purpose of this study was to determine the impact of the implementation of the policy of empowerment of villages in Riau province.

\section{B. METHODS}

This study used a qualitative research method descriptions. Researchers trying caught fact correspond to reality without the intervention of the conditions. Data collection techniques used adalan interviews and observation is a form of direct communication researcher and respondent. The interview took place in the form of question and answer. Furthermore documtation done by collecting written materials, data from documents, and literature then direct observation in the field to get heavy data corelation with this research.

\section{RESULTS AND DISCUSSION}

The complexity of poverty caused a chain problems can not be solved only with the purely economic approach but related to the dynamics of policy, social, political and cultural inherent in a community. Poverty reduction can be done to maximize all stakeholder involvement 
(Ema Fitri et. Al, 2014). The number of poor people in Riau province began in
2003 and 2004 (In Million People) can be seen in the following table:

Table 1. Central Bureau of Statistics, 2004

\begin{tabular}{ccc}
\hline Year & Number of Poor People & Percentage \\
2003 & 661.7 Thousand Souls & $15.6 \%$ Of Total Population \\
2004 & 1008.163 thousand souls & $22.19 \%$ Of Total Population \\
\hline
\end{tabular}

In solving the problem of poverty, the Governor of Riau has established the poverty Reduction Committee of Riau Province through Decree of the Governor of Riau No. 592 / IX / 2004. Team Poverty Reduction Committee (TKPK) Riau Province by facilitated Protection Agency and Empowerment (BPPM). TKPK drafting a development program consisting of the Regional Secretary, Planning Riau Province, Finance Bureau and the Regional Secretariat and BPPM DPRD Riau Province Riau Province formulating programs namely Village Empowerment Program (PPD). The program that drives the creation VILLAGE POWERED.

Helpless Village Program is a program that aims to build a system of values, especially for managers UED-SP and public funds beneficiaries of rural enterprises.PPD has done so by making three (3) pillars of core components, namely the strengthening of economic, community capacity building and strengthening the capacity of village officials. There is no program that combines education, learning, life skills, character development, participation, camaraderie and the provision of operating funds for the community. All three are done continuously by a cadre of community development, village assistant, regional coordinator, team leader of the provincial and provincial government representatives and district / city (province PMD, PMD District / City, Head, Head / village head). 
Figure 1. Flow of Village Empowerment Program Activity (PPD)

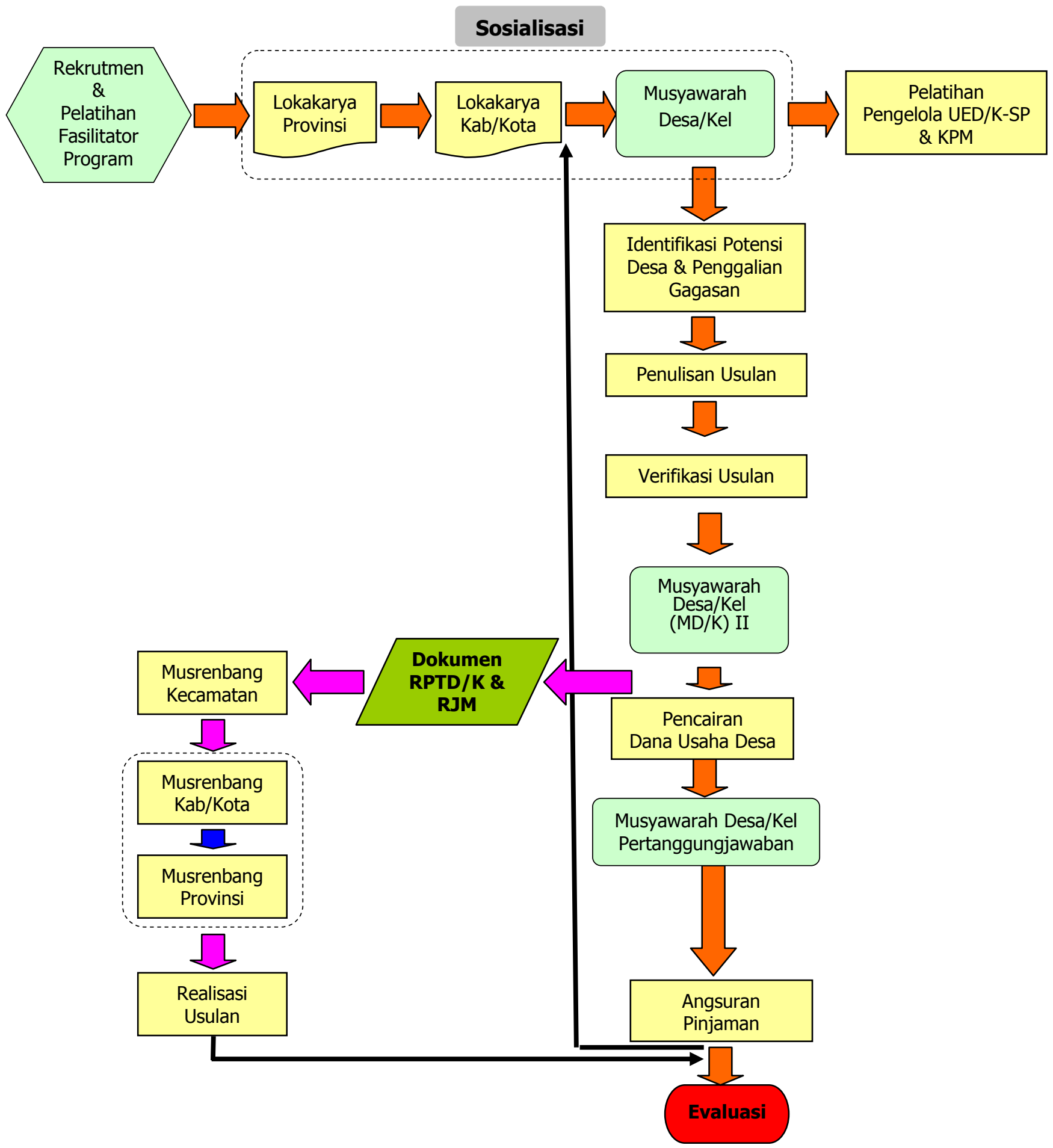


Figure 2: Organizational Structure of Village Empowerment Program (PPD)

Riau Province

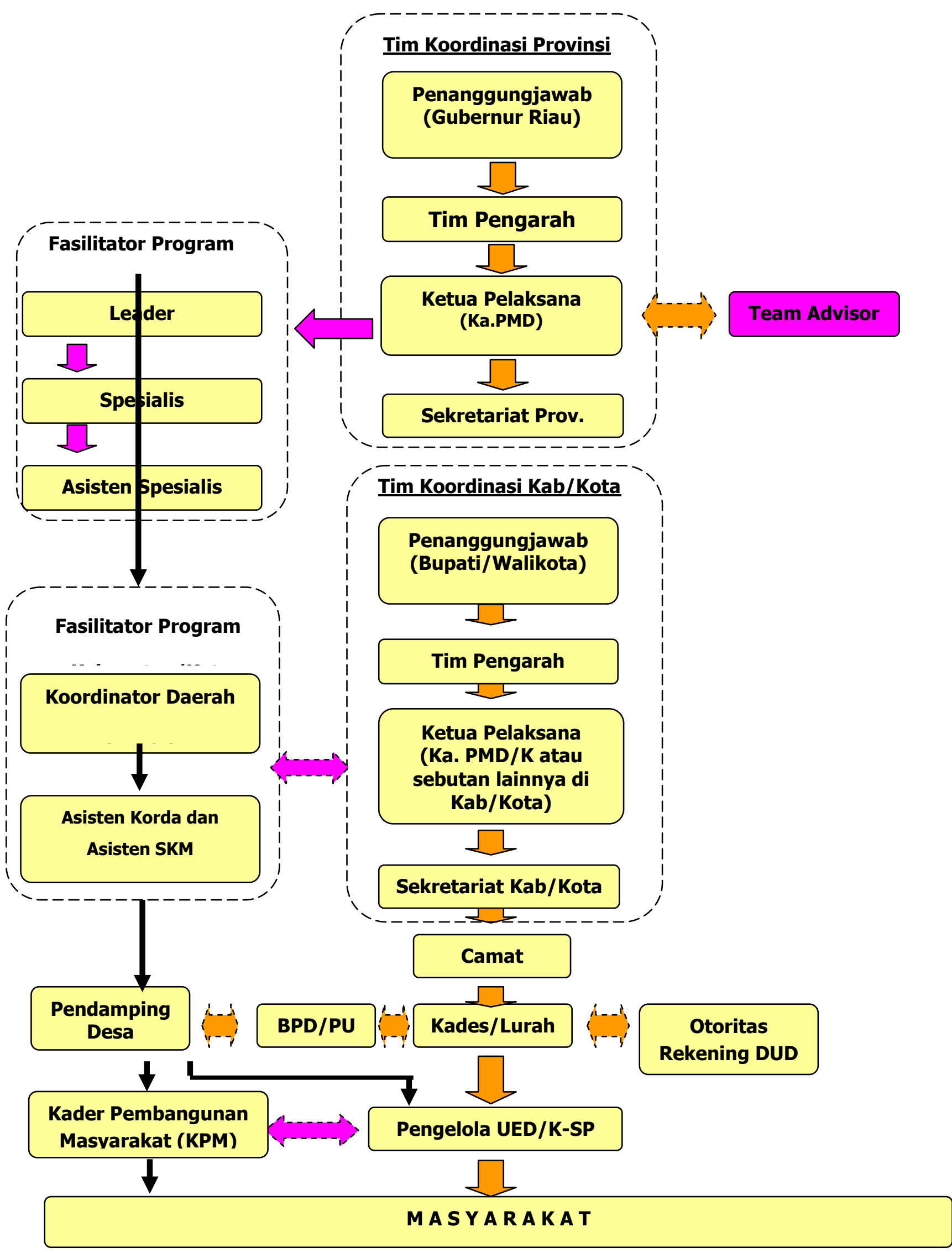


Figure 3. Structure of Institutional UED / K-SP Village / Sub

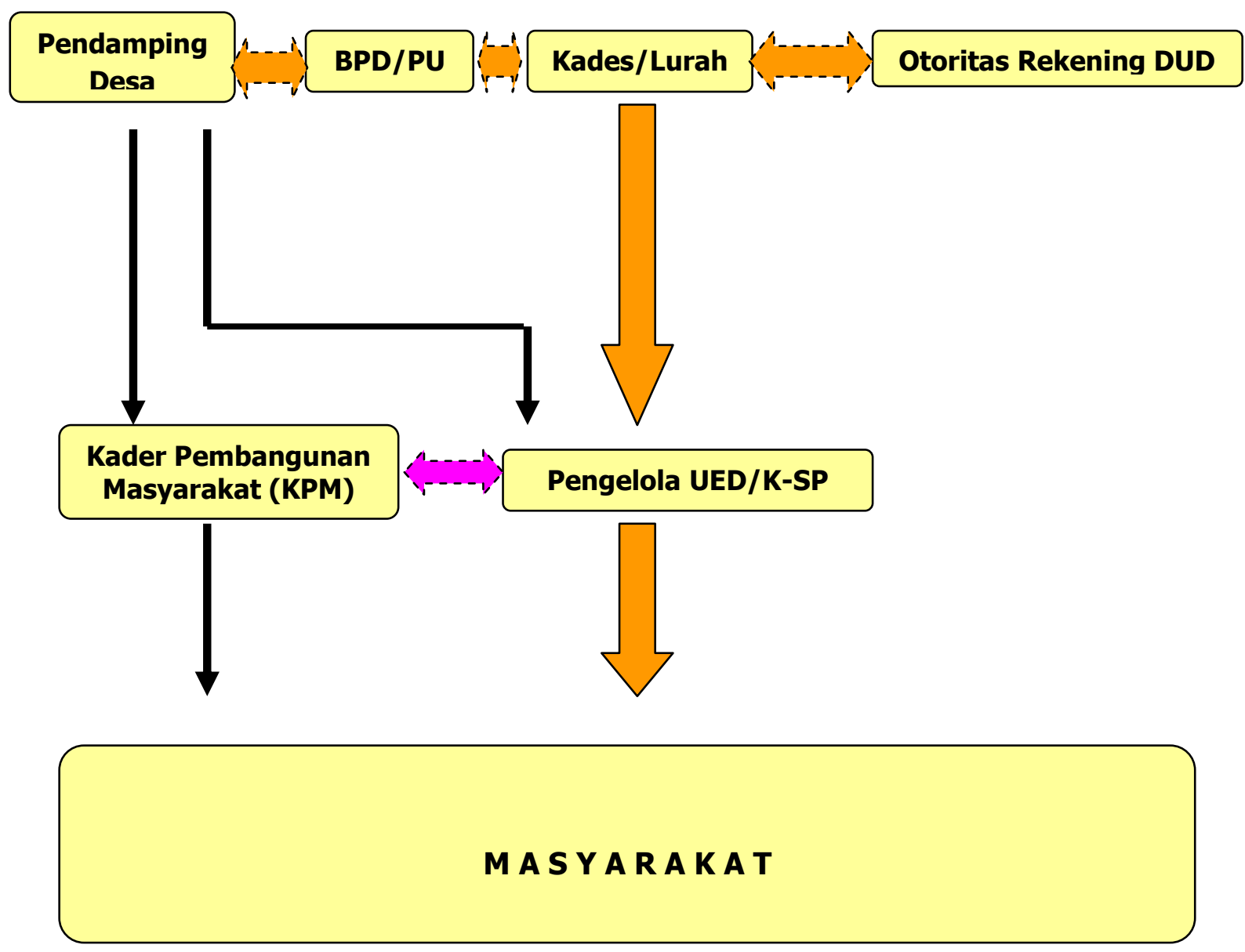

The value system that is built contained in the groove of the program. Strategies undertaken at the Village Empowerment Program are (a) Community Empowerment. The strategy is done through strengthening the education factor is done by providing information, make the transfer of science and technology, foster the rational mindset, stimulating participate in development, so it can be planted the seeds of "Modernization" in public life. Thus
PPD will become a vehicle for sociocultural learning for the community. (B) Capacity Building Society. PPD build institutional value system, especially for managers UED-SP and public funds beneficiaries of rural enterprises. A value system embodied in the groove awakened implementation that must be executed well by the actors and community programs (c) Community Economic Development. In the Village Empowerment Program (PPD) efforts to strengthen the control of society 
to economic resources is done by allowing the public to choose the activities relating to access to capital.Because for the economically disadvantaged, some sources mentioned economic progress is still a rare commodity and a major obstacle for their own empowerment. The small capital, low mastery of technology, narrowness and employment opportunities, limited development of human resources and market access are not under their control, often a major cause of dependence and underdevelopment of the lower layers of society. (D) Flow PPD is bottom up to accommodate the needs of the village. Groove starts from the recruitment of facilitators priority of location empowerment, socialization and workshops, identifying the needs of the village follow the musrembang, until the release of funds business based on the results of community meetings.

Involving all levels of government. Organizational Structure Program Village Empowerment (PPD) Riau Province puts the Governor of Riau as program leaders and was accompanied by the Head of PMD, Regency / City as coordinator, facilitator Program to escort villages and communities

Viewed from the implementation of empowerment programs (PPD) has been able to mobilize community participation since do this program, however, as a implementation found several problems that the authors wanted to examine how the impact of the implementation in terms of communication, resources, disposition and organizational structure forward edward III (1980).

\subsection{Communication}

PPD has several operating standards and norms are a reference and guidance for the guidance and control team and trainers PPD and PPD perpetrators village / villages in implementing the Program implementation process flow sequence. The standard is a reference in order to have a uniform policy communicated. Standards and norms are:

1. General Guidelines Explaining the rationale behind the need for an appropriate policy made in poverty reduction and rural development. In general guideline contains about technical policy, authority and procedures, guidance and management of the Village Enterprise Fund.

2. Technical Guidelines setting which includes the technical issues related to the implementation of the technical guidelines set in the PPD. Are contained within the flow of 
activities, management

principles, duties and responsibilities of actors PPD, reporting and monitoring mechanisms, as well as the handling of complaints and problems.

3. Finance and Administration Management Guide UED / KSP

Provision of Rural Enterprise Fund is expected to be developed in a transparent and accountability, for it required a manual or guide for managers on Village / Sub in administering financial statements. With the guidance occurred minimum administrative standards that must be owned by the manager of UED / K-SP. Thus the supervision and monitoring activities can be carried out more focused.

4. Program

Performance

Evaluation guide

Setting on procedures, mechanisms and evaluation processes PPD Program arranged in a performance evaluation guide. This guide contains indicators of performance indicators to be achieved by the facilitator PPD to achieve program objectives. The performance evaluation is intended to ensure that the process is carried out in accordance with the provisions and implementation stream PPD program. Cross-sectoral evaluation included an integrated manner with the involvement of Provincial Inspectorate Riau, Riau and BPK BPK RI Representative.

In addition, the communication was done instensive between communities and facilitators through tiered meeting. To facilitate the supervision and monitoring of village assistant must facilitate the implementation of PPD coordination meeting at the village / village no later than the 30th of each month. Furthermore village assistant and manager UED / K-SP is obliged to follow the district coordination meeting no later than the 5th of each month, facilitated by the coordinator daerah.kemudian later than the 10th of each month held provincial coordination meeting facilitated by the team leader.

\subsection{Resource}

human resources as a facilitator as many as 6,341 people, comprised of fulltime workers of the program facilitators as much as 407 people, managers and car 
loan as much as 2,348 people. As for parttime workers comes from the manager and $\mathrm{KPM}$, the number is 3,586 .

Resourse budget sourced from the budget and budget Provincial District / City. The program is intended for financing the Village Enterprise Fund sourced from the budget of Riau province and the city district budget. Village Enterprise Fund Budgeting is Riau Provincial Secretariat of Finance Bureau and Finance Department Secretariat of the Regency / City. While technical finance budgeting is at the Agency / DPM provincial and regency / city.

1. Each UED / K-SP PPD location before running the first service to the public are given training for managers for 1 (one) week with the financial management and administration of material UED / K-SP every year until 2013 held in April to June.

2. The whole facilitators comprised of a Team Leader, Regional Coordinator, Assistant Regional Coordinator and Assistant Village given the strengthening of capacity(asworkshops)at least once a year since 2005 until 2013.

3. Actors level PPD / District Village consisting of authorities DUD account (Village Head, Deputy Chairman of the LPM and female figures) and General Supervisor(ExOfficio Chairman BPD) socialization and training given by the provincial government and district / city government at least 1 (one) times a year;

4. The whole village assistant / sub obliged to foster two (2) community empowerment cadres (KPM) that is expected to continue the task of the facilitator in the process of empowerment that has been built through the post PPD assistance program.

\subsection{Attitude and disposition}

Attitude leader in PPD has been demonstrated by the establishment of Riau Governor Decree No. 592 / IX / 2004 dated September 6, 2004 on the establishment of the Poverty Reduction Committee of Riau Province. implementation commitment to various forms of efforts to improve the quality of PPD as:

1. A Team Development Coordination, Control and Evaluation of Rural Empowerment Program (PPD) through Riau Governor Decree No. Kpts. 004 / BPPM / III / 2005.

2. Establish General Guidelines and Technical Guidelines PPD Program Riau Province Riau Governor's Decree No. Kpts. 005 / BPPM / III / 2005; 
3. Program Performance Evaluation Guidelines stipulate PPD through Riau Governor Decree No. Kpts. 132 / III / 2005

4. The process of signing the Cooperation Agreement between the Government of Riau province and regency / municipal government with PT. Bank Rakyat Indonesia (BRI) in the framework of the Village Enterprise Fund distribution of Local Cash Account to the Village Enterprise Fund Account belongs Village Location PPD by the Cooperation Agreement No.. 04 / SKB / IV / 2005.

5. Changes in Operating Funds Distributors cooperation Bank village to PT. Bank Riau Riau Islands by the Cooperation Agreement Riau Provincial Government and District / City Government and Bank Riau Riau Islands by the Cooperation Agreement No.. 26 / DIR / 2011;

6. To revise General Guidelines and Technical Guide PPD through Riau Governor Decree Number. 15 Year 2006 as the adjustment conditions and needs;

7. Do the third revised General Guidelines and Technical Guide
PPD through Riau Governor Regulation No. 21 Year 2011

\subsection{Structure of the organization}

Structure of the organization which supports the development of PPD divided provincial coordination team, the team coordinating the district / city, facilitator, district coordination team. Provincial coordination team comprised of the governor in charge, the steering committee, the head of BPM as the chief executive and the provincial secretariat. District coordination team / town consisted of Regent / Mayor in charge, the steering committee, the head of BPM as executive chairman and the secretariat of the municipal district. While facilitators divided facilitator and facilitator Province District / City. Facilitator Provincial Program consists of leaders, specialists and assistant specialists and facilitators Regency / City consist of regional coordinators and assistant coordinators region. The team consists of a sub-district Sub-district, village chief / headman, village assistant, Kader Community Development (KPM), the manager of UED-SP. Details of the parties involved as follows:

1. Level Village / Sub. Head of Village / Sub responsibility for all activities. For the purposes of guidance and control activities at the village / village then defined as the party that 
performs the function of the Chairman BPD General Supervision (for the village) and one Community leaders selected in discussion village (for the village), established by the Decree of Regent / Mayor.

2. Districts. Camat primarily responsible for developing the implementation of sectoral

3. district / city. Regent / Mayor is Responsible for PPD activities in the districts / cities in the implementation of the activities was formed Coordinating Team Guidance and Control PPD district level through SK Regent / Mayor. Guidance and Control Coordination Team PPD Regency / City consists of (a) Regents / Mayors to be responsible. (B) Regional Secretary as Directors. (c) Head of Planning Agency as member of the Steering. (d) Head of Agency / Department / Community Development Office or any other name as the Chief Executive. (e) Head of Agency / Department / Community Development Office or any other name as the Executive Secretary. (f) Members of the Coordination Team Related OPD cross

4. provincial level. Riau Governor is Responsible for PPD in the province, the implementation of the activities was formed Coordinating Team
Guidance and Control PPD through SK Provincial Governor of Riau consist of: (a) the Governor of Riau as Responsible. (b) Regional Secretary as Directors. (c) Head of Planning Agency as member of the Steering. (d) Head of Community Empowerment and Rural Development (BapemasBangdes) Riau Province as Chief Executive. (e) Head of the Agency for Community Empowerment and Rural Development (Bapemas-Bangdes) Riau Province as Executive Secretary. (f) Members of the Provincial Coordination Team PPD element OPD traffic related.

5. Independent Monitoring Team of the Independent Monitoring Team by sampling at multiple locations responsible for monitoring and provide a report and recommendations to the Unit Responsible.

\section{Factors that affect the implementation of}

\section{rural empowerment}

1. the economic conditionsand character of the community are bound by the paradigm of earlier programs that only give money or goods, but no follow-up. Changing paradigms and character of rural communities postscript generally have the human resources are still relatively low is hard work to be done by the government. To 
overcome this, the program provides training for both facilitators village assistant, assistant cord, the cord or the team leader of the province of techniques to communicate the program properly.groups of Target poor people must be empowered as one charge of tasks and functions that must be undertaken by the empowerment of village assistant, so every month village assistant coaching must submit a report to the duty of the poor location regional coordinators

2. Commitment of regional heads, greatly affect the effectiveness of the PPD. For district / city regional heads are committed to understanding that was built together with the Governor of Riau and provide budgetary support and other resources, the region will succeed in implementing the program for example like Rokan Hulu (managed to become a pilot development UED-SP / BUM Village nationally year 2013). Conversely areas with less regional head / do not support the effectiveness and the distribution of funds is very low rural enterprises. For those areas that do not get the full support of the Head of the terrain is, the Provincial Government may provide additional funding allocation of rural enterprises and other supporting activities.

3. This program has been able to answer the needs of the people or the people of Riau, especially in relation to the problems of access to capital, the availability of infrastructure, the impacts of weather and natural disasters, the ownership of production assets, the exchange rate of farmers / fishermen and even youth and socio-cultural issues and health by maximizing the role of companion village.

4. Currently there is no poor word for poor people in Riau who are willing and earnest to try. Because the pockets of poverty have been presented by village economic institutions (UED / K-SP) by the Government of Riau Province in cooperation with the District / City Government. Now thousands of village economic institutions have grown into Village Owned Enterprises (BUM Desa) whose role is not only in the business service sector of the community economy but can even contribute to the original income of the village which is one of the funding sources in APB Desa for development 
Changes in vision, mission Riau Governor elect. Once elected a new governor in the election of the Governor of Riau in 2013, the vision and mission of Governor candidates are offered at the time of the elections to be a reference in the preparation of the vision and mission of the provinces. Therefore, a change in the fundamental direction of the previous policy. So that in 2014 the distribution of financial assistance and facilitation of rural enterprises ended. But the guidance and supervision remain to be done by the Riau provincial government through the Institute for Rural Economic Development Program (PPLEP).

\section{CONCLUSION}

The scenario in the PPD directing the creation of conditions and environments that allow people to enjoy a better life while giving a wider opportunity to the public to make choices freely and independently in accordance with the potential and the characteristics they have proved successful, Given discretion in identifying community needs, formulate and implement development plans in a participatory manner, thus providing a sense of responsibility and a high sense. Pain has made people actively monitor and supervise the implementation of the PPD program and other development programs.
In the Village Empowerment Program (PPD) efforts to strengthen the control of society to economic resources is done by allowing the public to choose the activities relating to access to capital. Because for the economically disadvantaged, some sources mentioned economic progress is still a rare commodity and a major obstacle for their own empowerment. The small capital, low mastery of technology, narrowness and employment opportunities, limited development of human resources and market access are not under their control, often a major cause of dependence and underdevelopment of the lower layers of society. Though these factors is a prerequisite of empowerment that is absolutely necessary.

Through the implementation of the PPD has become a medium of learning and development capability development actors, as well as the media to create a society as initiators in a development activity. PPD concept development is also directed to the implementation of good government.

\section{E. ACKNOWLEDGMENTS}

Thanks to Gerry head of division as service parts in Riau which has facilitated the researcher for data retrieval, and then thanks to Mr. junaidi in rural empowerment agency in Riau who 
collaborated with researchers in this study and make a study of rural empowerment as form of service innovation.

\section{REFERENCES}

Edward III, George C, 1980, Implementing public policy, congressional quarterly press ine, washington DC

Ema pure. et. al. 2014. The implementation of the national program of empowerment of women. Journal of Development Administration. Vol 2, No. 2. It. 221226 [3]
Grindle, erilee S. 1980. Politics and Policy Implementasion in the third word, princeton University Press. New Jersey.

Maliki Wahyu, 2012. Analisis Implementasi Kurikulum Seni Budaya Keterampilan di Sekolah Dasar Nasional 1 Bekasi Jawa Barat. Tesis. Fakultas Ilmu Sosial dan politik. Universitas Indonesia.

Tangkilisan, Hessel Nogi S 2008, the policy and management of regional autonomy. Yogyakarta; Lukman Offset 